\title{
Egyenes esztergakés élgeometriájának tervezése, modellezése és vizsgálata
}

\section{Designing, modelling and analysis of straight turning tool geometry}

\author{
Cs. NEMES ${ }^{1}$, S. BoDZÁS² \\ ${ }^{1}$ University of Debrecen, csabanemes94@gmail.com \\ 2University of Debrecen, bodzassandor@eng.unideb.hu
}

Absztrakt. A publikációban az egyenes esztergakés élgeometriájának és modelljének a létrehozását valósítjuk meg szoftver segítségével a modelltérben. Célunk egy olyan program létrehozása, amely néhány hossz- és szögméret megadásával kiszámítja az annak megfelelő élgeometriát. Ezt drótváz modellként alkotja meg egy olyan fájlformátumban, ami könnyen átvihetô a ma használatos CAD szoftverekbe, így ott az esetleges további változtatásokat végre lehet hajtani. Végeselemes-szimuláció segitségével adott technológiai paraméterek és anyagminőség mellett meghatározható egy optimális élgeometria a lehető legjobb forgácsolási viszonyok elérésének érdekében.

Abstract. We execute the planning, modelling and examination of straight turning tool geometry with the help of a software in the modelling space. Our aim is to create a programme that - given some lengths and angles calculates the corresponding geometry. It establishes that as a wireframe model in a file format that is easily transmittable to the CAD softwares of today, so any additional changes can be done there. An optimal geometry can be defined for the best possible chipping conditions using finite element simulation and with given technological parameters and material quality standard.

\section{Bevezetés}

A forgácsoló szerszámok élgeometriájával jelentősen befolyásolhatjuk a forgácsolási folyamatot [2, 5, 7]. Gazdasági szempontból nem közömbös ugyanis, hogy a lehető legoptimálisabb élgeometria kerüljön alkalmazásra, amely kedvező forgácsolási viszonyokat eredményeznek.

$\mathrm{Az}$ optimalizációs folyamatot valamilyen paramétereket figyelembe véve lehet idealizálni. Törekedhetünk például a szerszáméltartam- vagy a fajlagos anyagleválasztás növelésére, vagy a számunkra legkedvezőbb forgácsalakban történjen az anyagleválasztás (töredezett, elemi, folyóforgács stb.). Lehet még cél a forgácsolt felületminőség javítása, vagy az előbb említett paraméterek javítása egyszerre, azonban ilyenkor természetesen bizonyos kompromisszumokra is szükség lesz $[1,4,5]$. 
A modellező szoftver létrehozására azért volt szükség, mert így gyorsan és könnyen létrehozhatóak különböző élgeometriájú forgácsolószerszámok a modelltérben. Egy ilyen szerszám modellezése bonyolult és időigényes, valamint nagyon könnyű elhibázni összetettsége miatt. A programunk matematikai úton határozza meg a modellt, így az biztosan egzakt lesz.

\section{A modellező program}

A hagyományos esztergakés geometriáját térbeli egyenesek segítségével írjuk le. Ez azt jelenti, hogy bizonyos egyszerűsítéseket végzünk a szerszámon a meghatározásához. Elhanyagoljuk a lapkarögzítést és az íves felületeket. Így nem vesszük figyelembe a szerszámcsúcs lekerekítést és a forgácstörő hornyot sem. A szerszámon nem ábrázoljuk a szerelhető lapkát sem. Az egyszerūsítések elvégzése és a koordinátarendszer felvétele után a következő modellt kapjuk (1. ábra).
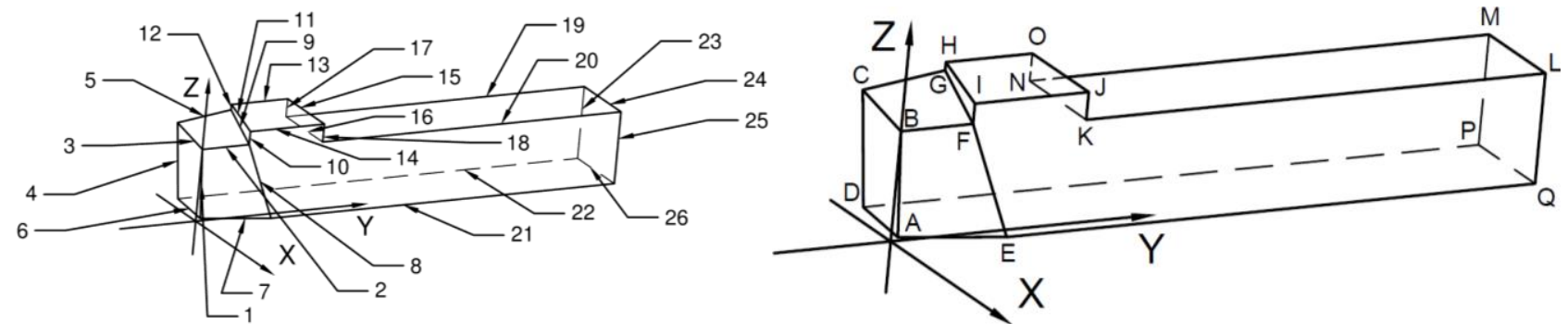

1. ábra: Drótváz modell a térbeli egyenesekkel és a sarokpontokkal

Ezek a sarokpontok szintén a térben helyezkednek el, tehát a meghatározásukhoz az X-Y-Z koordináták szükségesek. Mivel a forgácsolószerszámok geometriáját szögekkel és hosszméretekkel jellemezzük [7, 8], ezért úgy kell rendezni a térbeli egyenesek egyenleteit, hogy ezeket a szögeket és hosszméreteket megadva a programunkban számíthatóak legyenek a sarokpontok helyzete a modelltérben.

A következő ábrákon látható hosszméreteket, illetve szögméreteket kell megadnunk a drótváz modell meghatározásához (2. ábra). Egyszerűségi okokból az ortogonál szerszámszög rendszer került kiválasztásra a szögméretek megadásához [5]. Törekedtünk arra, hogy a lehető legkevesebb paraméter megadásával tudjuk meghatározni a forgácsolószerszámot. 


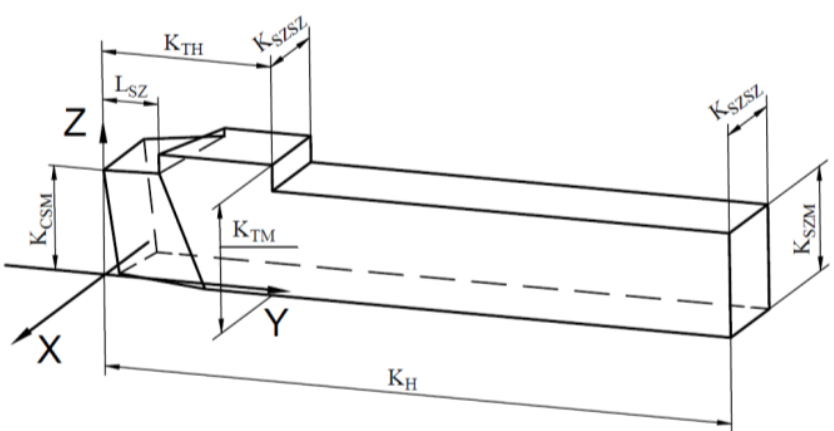

2. ábra: A drótváz modell meghatározásához szükséges hossz-és szögméretek

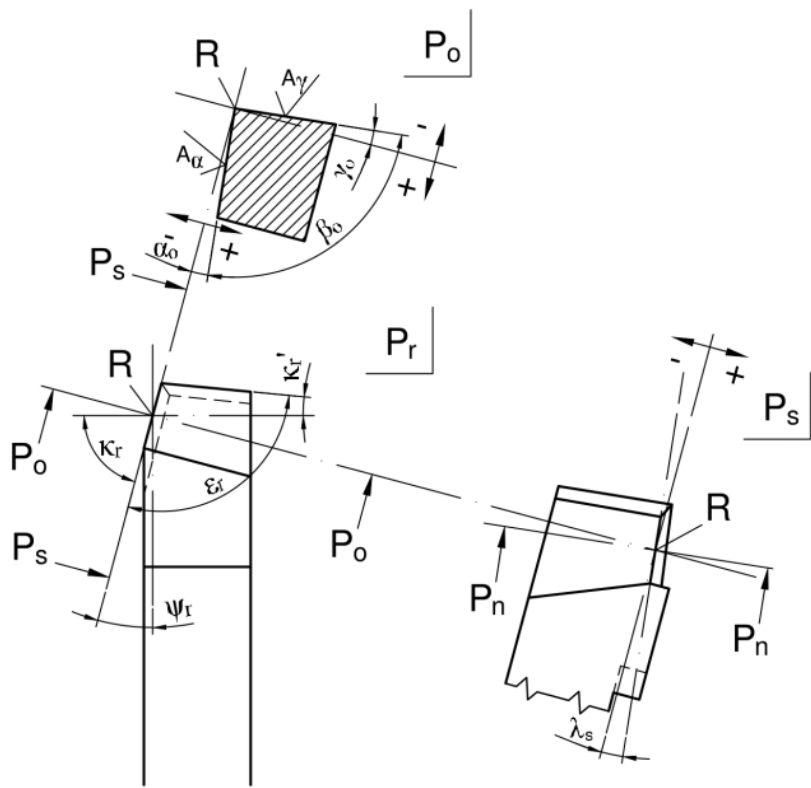

Ezután az egyenletek programozására, illetve a modellező program létrehozására került sor. A program a fejlesztői környezet nélkül, önállóan is képes múködni. Grafikus felülettel rendelkezik, ami megnyitás után így jelenik meg (3. ábra).

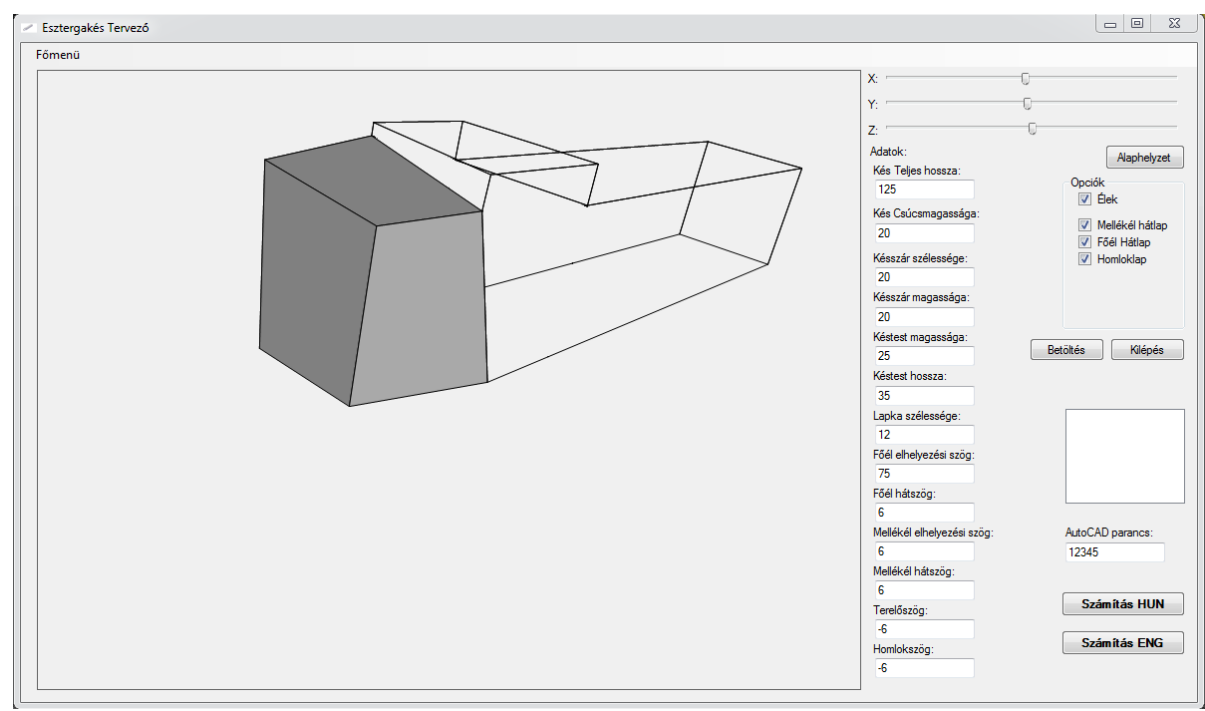

3. ábra: A modellező szoftver megjelenése megnyitás után

A program két részre osztható. A jobboldali rész a kezelőfelület. Itt kell megadnunk a szükséges méreteket, illetve itt adhatunk parancsot a modell kimentésére. A baloldali rész egy képernyő, ami a megadott méreteknek megfelelően kigenerált drótváz modellt jeleníti meg. A modell körbeforgatható. Opciók menüben lehetőségünk van az élek és a felületek megjelenítéséhez. Az „Alaphelyzet” gombbal a megnyitás utáni eredeti állapot állítható vissza. A „Számítás” gombra kattintva a szokványos ablak ugrik fel, ami a megadott értékeket menti ki tetszőleges helyre és néven a megadott fájlformátumban.

A modellező szoftver által generált drótváz modellt lehetőségünk van egy CAD programban megnyitni. Itt további módosítások végezhetőek rajta tetszés szerint. Az importálást követően körül kell zárnunk 
egy vízhatlan térrészt, a szerszám belső terét. Ezután CAD szoftvertől függően használt konvertáló parancsot alkalmazva szilárdtestté alakítjuk át.

\section{Szimuláció és eredmények}

A szimulációk során egy munkadarab anyagminőséget és egy szerszám anyagminőséget használtunk. A szimulációkat kétféle élgeometriával futtattuk le. Minden szimulációban ugyanazokat a végeselemes és a technológiai paraméterek állítottuk be. A dolgozó rész felfogható a gyakorlatban használatos szerelhető keményfém lapkához. Az egyik szimuláció során használtunk csúcssugár lekerekítést, míg a másiknál nem.

A végeselemes szimulációban a Johnson-Cook anyagmodellt [6] választottuk. A modellben a folyáshatár függvénye a képlékeny alakváltozásnak, az alakváltozási sebességnek és a hőmérsékletnek. A tagok közötti összefüggés az alábbi képlettel írható le.

$$
\sigma=\left(A+B \cdot \varepsilon_{p}^{n}\right)\left[1+C \cdot \ln \left(\frac{\dot{\varepsilon}}{\dot{\varepsilon}_{0}}\right)\right]\left[1-\left(\frac{T-T_{r}}{T_{m}-T_{r}}\right)^{m}\right]
$$

Továbbá szintén a Johnson-Cook [6] által publikált egyenletet alkalmazzuk az anyag tönkremenetelének leírásához. Az egyenlet a következő:

$$
\begin{aligned}
& \varepsilon^{f}=\left[D_{1}+D_{2} e^{D_{3} \sigma^{*}}\right]\left[1+D_{4} \ln \left(\frac{\dot{\varepsilon}}{\dot{\varepsilon_{0}}}\right)\right]\left[1+D_{5}\left(\frac{T-T_{r}}{T_{m}-T_{r}}\right)\right] \\
& \text { nyomás tényező alakváltozási hőmérséklet } \\
& \text { sebesség tényező tényező }
\end{aligned}
$$


Az eredmények mind 10\%-os hibahatáron belül vannak. A képeken esztergálás közbeni hőfejlődés látható (4. ábra).

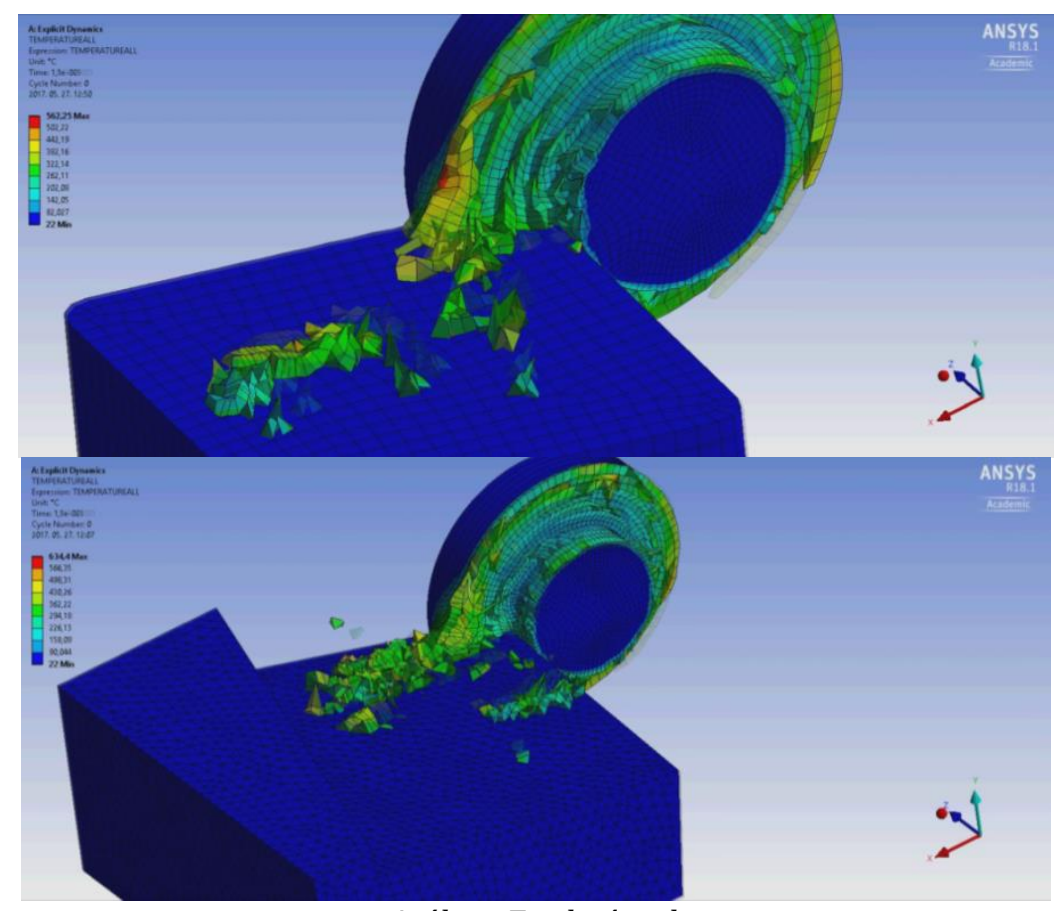

4. ábra: Eredmények

\section{Hivatkozások}

[1] Bakondi K., Kardos Á. (1966) A gépgyártás technológiája, I. Forgácsolás, Második kiadás, Tankönyvkiadó, Budapest. p. 382.

[2] Bálint L. (1958) A forgácsoló megmunkálás tervezése, Műszaki Kiadó, Budapest.

[3] Ducsai J. (2013) Forgácsolási eljárások, Tankönyvmester Kiadó, Budapest. ISBN 978-963275-082-8

[4] Fridrik L. (2011) Forgácsolás I., (Forgácsoláselmélet), Miskolci Egyetemi Kiadó, p. 206.

[5] Gyáni K. (1979) Gépgyártástechnológia alapjai I., Tankönyvkiadó, Budapest. p. 131.

[6] Johnson G. R., Cook W. H. (1983) A constitutive model and data for metals subjected to large strains, high strain rates and high temperatures, Proceedings 7th International Symposium on Ballistics, The Hague, 19-21 April 1983, p. 541-547.

[7] Kozma F. (1995) Forgácsoláselmélet, Kossuth Lajos Tudományegyetem, Műszaki Főiskolai Kara, Debrecen.

[8] Kozma F. (1996) Forgácsolás technológiája I. (Esztergálás, Gyalulás, Vésés és Üregelés), Kossuth Lajos Tudományegyetem, Műszaki Főiskolai Kara, Debrecen.

[9] Mankovits T., Huri D. (2015) Modellezés és szimuláció (A lineáris rugalmasságtan és a végeselem-módszer), Debreceni Egyetem. 
[10] Nemes Cs., Bodzás S. (2017) Egyenes esztergakés tervezése, modellezése és vizsgálata, Műszaki Tudomány az Észak - Kelet Magyarországi Régióban 2017, Konferencia Előadásai, Nyíregyháza, 2017.06.01., p. 333-339, ISBN 978-963-7064-35-7

[11] Páczelt I., Szabó T., Baksa A. (2007) A végeselem-módszer alapjai, készült a HEFOP 3.3.1-P.2004-09-0102/1.0 pályázat támogatásával

[12] Zhang, Y., Outeiro, J.C., Mabrouki, T. (2015) On the Selection of Johnson-Cook Constitutive Model Parameters for Ti-6Al-4 V Using Three Types of Numerical Models of Orthogonal Cutting, 15th, CIRP Conference on Modelling of Machining Operations, Procedia CIRP, Volume 31, p. 112-117. Letöltés ideje: 2017.08.10. http://www.sciencedirect.com/science/article/pii/S2212827115002504 